\title{
Scholarly Communication as a Loosely Coupled System: Reassessing Prospects for Structural Reform
}

\section{Charles A. Schwartz}

\begin{abstract}
Scenarios of restructuring the scholarly communication system have dominated our profession's view of how major problems confronting libraries will have to be resolved. This paper comes to a different view. It suggests that any fundamental reform would presuppose an interdependent system, one with a fair amount of integration or consensus. Scholarly communication, however, is in reality a loosely coupled system of largely autonomous constituencies with little communication, coordination, or even direct cause-and-effect relationships. Loose coupling reflects certain functional needs, such as flexibility, local adaptation, and innovation, afforded by such "organized anarchy." This structural property of loose coupling is the essential reason why structural reform is an unrealistic prospect and a poor idea, since it would run the risk of impairing the system's capacity to handle constant environmental change. The paper concludes with some suggestions for alternative approaches to future research and analysis in this area of inquiry.
\end{abstract}

ver the past decade, study of the scholarly communication system has attracted broad interest in the library field. The consensus is that the system has broken down under the combined weight of price inflation and publication proliferation, and that restructuring it will require major allied actions on the part of the nation's universities.

Three scenarios of structural reform dominate discussion. One scenario is technological; it anticipates a historic transformation of scholarly communication from the print age to the electronic era now under way. ${ }^{1}$ Another scenario concerns the publisher base; it envisions university presses greatly expanding their role, particularly in science and technology journals, with the aim of displacing the monopoly position of commercial presses. ${ }^{2}$ The third scenario focuses on the academic rewards system; it foresees administrators making a concerted move toward qualitative measures of faculty research performance, with the aim of displacing the publish-or-perish syndrome of insignificant articles. ${ }^{3}$

How well do those scenarios capture the likely prospects for structural reform? Taken literally, none of them can be assessed very realistically: Each scenario is indeterminant about the shortterm future. In the case of technological transformation, this difficulty is understandable. Writers generally refrain from

Charles A. Schwartz is Social Sciences Librarian at the Fondren Library, Rice University, Houston, Texas 77251-1892; e-mail: schwart@ricevm1.rice.edu. The author wishes to thank Gary D. Byrd, Dennis Carrigan, Richard M. Dougherty, Karen Hunter, David Kaser, Susan K. Martin, Charles B. Osburn, and Herbert $S$. White for their helpful comments on an earlier draft of this paper. 
making specific projections on technological development because of the known tendency to overestimate what is possible in the short run and underestimate what could happen in the long run.

For the other scenarios involving concerted initiatives on the part of the nation's universities, the indeterminate nature of discussion is troublesome. There is no time frame or specific plan, only an expectation that the "sleeping giant of higher education will soon wake up" to the need for structural reform. ${ }^{4}$ Nor is any salient role assigned to libraries. Rather, the literature in our field stresses that libraries, as captive markets, are in a dependent position in the system, with little potential for collective action.

\section{This structural property of loose} coupling is the essential reason why structural reform, which presupposes a considerable degree of integration and consensus in the system, is a poor theory and an unrealistic prospect.

Overall, the issue of prospects for structural reform has reached an impasse. Libraries have, in effect, placed the burden of responsibility on groups and events beyond their sphere of control. At the same time, a decade of deliberation in our field on the plausibility of such wishful scenarios has stunted consideration of real-world approaches that are practical and within our control. As Karen Hunter has observed, it is rather "bewildering that there are relatively few articles on what can be done to improve access [now]. Instead, the emphasis is on creating a utopia for the twenty-first century."

To assess the realism of the three scenarios, a fundamental shift in perspective is necessary. Underlying all the scenarios is a basic assumption: that scholarly communication constitutes an interdependent system. This assumption originated in The National Enquiry into Scholarly Communication, a 1979 report by the American Council of Learned
Societies (ACLS). The report begins with an "axiom" that the "various constituencies involved in scholarly communication-the scholars themselves, the publishers of books and of learned journals, the research librarians, the learned societies-are all components of a single system and are thus fundamentally dependent upon each other." 6 A few pages later, the report picks up that thought once again with the assertion that, although different constituencies may adopt conflicting approaches to particular problems, the "binding forces, the common interests, are ultimately stronger." Yet, nowhere else in the 166-page report is system interdependency even mentioned. Evidently, it was included as a matter of presumed logic (that systems are supposed to be interdependent) or normative value (that all groups should cooperate).

The impact of those brief passages has been profound. As Charles Osburn has pointed out, while the report's findings and recommendations were soon forgotten, its notion of an interdependent system paved the way for scholarly communication to become a research area in its own right. ${ }^{8}$ Discussion since then has adopted a refrain that the problem is systemic and its solution must address the entire system of scholarship, from the production of research to its dissemination and rewards. Perhaps more than any other idea, that dual image of system interdependency and structural reform has shaped our view of how major problems confronting the library field will have to be resolved.

The analysis presented here comes to a different view. It suggests that scholarly communication is not an interdependent system in any meaningful sense, even theoretically. Rather, it is a loosely coupled system, comprised of largely autonomous components with little communication, coordination, or even direct cause and effect relationships. This structural property of loose coupling is the essential reason why structural reform, which presupposes a considerable degree of integration and consensus in the system, is a poor theory and an unrealistic prospect. 
Loose coupling does not require us to conclude that nothing can be done, through deliberate plan, to improve the operation of the scholarly communication system. But it does point up the need to consider the remoteness of grand structural reform and its likely futility, as well as question its very relevance. Loose coupling is not accidental or incidental, nor does it represent a flawed system. It reflects certain functional needs, such as flexibility, local adaptation, and innovation, afforded by such "organized anarchy." 9 In this perspective, structural reform-to the extent that it means tightening up patterns of influence or interaction for the sake of institutional order, as reflected in the scenario of a university-based publishing apparatus-would run the risk of impairing the system's capacity to handle constant environmental change.

Beyond this introductory sketch, the analysis is developed in five main parts. Part one describes the origin of the assumption of system interdependency. Part two sets out a model of scholarly communication as a loosely coupled system. As opposed to the previous literature, in which interdependency is an assumed condition, this model treats it as an independent variable. Part three surveys a few components of the system where tightly coupled patterns of influence or interaction are prevalent. Part four assesses certain prospects for electronic development of the system and how such development would affect its loosely coupled structure. The last part outlines some suggestions for future research and analysis.

\section{ORIGIN OF THE ASSUMPTION OF INTERDEPENDENCY}

The economic recession in higher education during the early 1970 s, following the end of the "Great Society" spending spree on academic libraries, brought an initial shock at the real (unsubsidized) cost of scholarly publishing. Executive committees of learned societies made swift cuts in the size of their serials. ${ }^{10}$

Hardest hit were the university presses. The book budgets of academic libraries fell so suddenly that many presses were caught with unsalable inventory. Price increases, intended to make up for lost revenue, depressed sales further. Then in 1973, a group of university press directors asked the ACLS to undertake a study of trends affecting scholarly publishers and academic libraries. In 1975, following two conferences and a $\$ 600,000$ funding drive, The National Enquiry was launched.

When the report came out four years later, however, the university press directors denounced it as "trivial, if not downright silly ... poorly formulated, inadequately researched, badly interpreted, and presented with overstatements, contradictions, and logical fallacies." their specific criticisms is hardly necessary, since the report had only one lasting impact: its notion of system interdependency, which the press directors dismissed as "simplistic." 12 The only recommendation that came to pass-the creation of an Office of Scholarly Communication within ACLS itself-folded after a few years.

\section{MODEL OF A LOOSELY COUPLED SYSTEM}

A "system" is not simply or necessarily interdependent. Systems vary significantly in the extent to which components and processes constitute an integrated whole, one with salient cause and effect relationships. In a now famous paper, Karl Weick introduced the concept of loose coupling to convey the image of two structural properties of large-scale social systems: component semiautonomy and means-ends ambiguity. ${ }^{13}$

\section{Component Semiautonomy}

In a loosely coupled system, components are somewhat responsive but essentially autonomous. Their connections may be sudden (rather than continuous), occasional (rather than frequent), negligible (rather than significant), indirect (rather than direct), or eventual (rather than immediate).

Thus, connections in the scholarly communication system may appear suddenly:

The advent of the computer had such jolting impact on scholarly communica- 
tion, primarily because of the swiftness of change it generated, that it is very largely responsible for the attention now given to scholarly communication as a system. ${ }^{14}$

Further, connections in the scholarly communication system may occur occasionally, as campus administrators generally do not maintain regular communication with either library directors or university press directors. Connections may be negligible, with libraries tending to preserve their institutional autonomy and freedom of action within resource-sharing programs. Connections may be indirect; publication proliferation (as discussed below) is an offshoot of the growing complexity of the modern world and the size of higher education, and is not tightly coupled to either the publish-or-perish syndrome or the academic rewards system. Connections may be eventual, as illustrated by the fact that the economic recession that got under way in higher education in 1970 did not begin to influence library perceptions or practices until the latter half of that decade.

\section{Means-Ends Ambiguity}

The other major structural property of a loosely coupled system is that organizational means and ends (costs and benefits, inputs and outputs) may have ambiguous relationships. There is an absence of functional linkages to support a theory of organizational effectiveness.

Such loose coupling, to take a familiar example, pertains to collection development in academic libraries. Bibliographers are somewhat responsive to general or interdisciplinary concerns but work basically on their own, with fluid participation on the part of faculty. Means and ends are not closely tied: collection goals are broad and idealistic; selections are problematic owing to the extraordinary growth, price inflation, and uneven quality of scholarly publishing; technology for collection evaluation is hazy; and there is little feedback about the eventual use or value of a given selection. ${ }^{15}$

In contrast, tight coupling refers to interdependent subsystems or, within an organization, to direct means-ends relationships that can be controlled, restructured, or at least understood in systematic ways. Loose and tight couplings can be used as building blocks in modeling the complex workings of the scholarly communication system. The few general accounts of this system published up to now describe its various constituencies with little attention to their actual patterns of influence or interaction.16 In other fields, coupling analysis is one of the more powerful ways of depicting large-scale system complexity; about 300 such studies have been done.17 One advantage is the flexibility it affords theory-building; readers can add, critique, or rearrange certain blocks (sets of couplings) without having to rethink the whole conceptual scheme.

\section{Libraries and Academic Institutions}

An image of loose coupling between academic libraries and their parent institutions is evoked by a number of longstanding concerns. One is the general lack of regular communication between library directors and deans. Conventional wisdom holds that the library suffers from a kind of benign neglect because it does not pose either great problems or great opportunities. ${ }^{18}$

The relative autonomy of the library, however, need not be viewed pejoratively. It reflects a certain logic of confidence associated with loosely coupled systems in which "parties bring to each other the taken-for-granted, good faith assumption that the other is, in fact, carrying out his or her defined activity." ${ }^{19}$ Tightening up such patterns of interaction would be a reciprocal process involving a greater role for the faculty in the governance of the library. Librarians, understandably, may not be very comfortable about such faculty involvement. ${ }^{20}$

Another concern indicative of loose coupling is the absence of direct exchange relations between the library and the faculty in the political economy of collection development:

Library directors, who have responsibility, lack authority. Faculty members, who have authority, lack responsibility. University administrators, who at least conceptually have 
both authority and responsibility, have abdicated both when it comes to libraries. Many librarians have virtually no contact with administrators except in times of painful financial discussions. ${ }^{21}$

Such dispersion of power is reinforced by a third concern: the lack of cost-benefit analysis to indicate how investments in library resources are related to gains in campus productivity. Little wonder that administrators find it easier to discuss the symbolic importance of the library than to defend or refute its budget requests, which do not have even theoretical limits. ${ }^{22}$

\section{Library Networks}

It is easy to describe the American library system, with its extraordinary decentralization, as loosely coupled. Each library has a unique culture, with its own organizational mission and freedom of action. What is troublesome about that truism, however, is that librarians are influenced by certain opposing professional norms (normative linkages) about "the way things should be." Against the norm of organizational autonomy is the counternorm of network interdependency, which calls for cooperative arrangements to cope with the growth and inflation of scholarly publishing.

University administrators, who at least conceptually have both authority and responsibility, have abdicated both when it comes to libraries.

The dichotomy between autonomy and interdependency has not been dealt with satisfactorily in the library literature. Discussions have tended to be speculative and abstract, as in the 1970's model of "Combined Self-Interest," based on the ideal assumption that research libraries' strengths and weaknesses can be combined rationally in regional schemes of coordinated collection development. ${ }^{23} \mathrm{Or}$, when discussions have turned to debates, writers treat the professional norm and counter- norm as rhetorical devices. Clearly, whatever insights we might gain in the autonomy-interdependency dichotomy must come from broader considerations than the norm-counternorm frame of analysis. A brief sketch of some discontinuities in library interdependency over the past half-century might put this problem in better perspective.

Toward the end of the Second World War, Robert Downs made a precursory case for coordinated collection development, arguing that it was impossible for even the largest libraries to hold more than a fraction of the world's literature. ${ }^{24}$ Yet, this proposition took thirty years to become a professional norm. Until the mid-1970s, organizational autonomy-reflecting the "bigger is better" philosophy of collection management-overshadowed the idea of network interdependency.

Strikingly different was the latter half of the 1970s. That was the period in which coordinated collection development became what theorists call an "institutionalized thought structure." 25 Whereas only a handful of consortia had been established between 1931 and 1972, fifty-three new consortia comprising at least one member of the Association of Research Libraries (ARL) were set up between 1975 and 1982.

The early 1980s marked a third period of discontinuity, as the immense difficulty of taking interdependency from theory to practice became evident. As reported in a national survey, nearly all collection development consortia became stymied in the attempt to move beyond the beginning stage of fostering organizational relationships to the point of determining specific goals and responsibilities. Indeed, once participants became aware of the sheer diversity of organizational interests and collection management structures, they found themselves unable to specify even the general aims of their respective programs. ${ }^{26}$

Over the past decade, the autonomyinterdependency dichotomy seems to have disappeared from active consideration. We now take for granted that libraries inevitably preserve their freedom of 
action within consortia, finding joint acquisition interests only on the margins of academic programs. The transition in paradigms from resource-sharing to "access, not ownership" has reinforced such freedom, since the optimal or affordable level of access is a local prerogative.

\section{Scholars}

Despite their central role in thescholarly communication system, scholars themselves have relatively bounded perspectives. This situation is evident from their segmented schools of thought, as well as their incomprehension of the system at large.

The fragmentation of scholars into rather isolated schools of thought is a familiar but barely understood process. So far, no model of the growth of knowledge has managed to account for the extent of "disconnectedness" in communication ties between scholars. The broad effects of such fragmentation on the workings of the scholarly system, however, are clear enough. Research specialization (a function of intellectual efficiency) and research diffusion (a function of the growing complexity and uncertainty of the modern world) proceed in a mutually reinforcing fashion. The proliferation of journals generates new opportunities for debate, leading to even more highly specialized research aimed at nearly exclusive audiences, who become increasingly selective in their reading.

Since the 1960s, that process has swept away much of the intellectual unity of the various disciplines. Learned societies now encompass scores of diverse groups with competing scientific or humanistic values and practitioner interests. ${ }^{27}$ While such conflicts have subsided in those learned societies no longer capable of close communication, they still tend to disrupt campus politics. As a primer on faculty governance warns, "Authoritarianism and chauvinism within the academic disciplines pose more direct barriers to collegiality than the most autocratic of administrators." 28

Scholars apparently do not fully grasp, let alone appreciate, the concept of an interdependent scholarly communication system. That concept is almost completely absent from the literatures of the physical sciences, the social sciences, and the humanities. As a rule, scholars have no real interest in the organization or finance of scholarly communication beyond their own immediate needs. ${ }^{29}$ Some partial exceptions-episodes of broader awareness in the early 1970sonly serve to support the rule.

\section{Research specialization (a function of intellectual efficiency) and research diffusion (a function of the growing complexity and uncertainty of the modern world) proceed in a mutually reinforcing fashion.}

In 1972 Robert Lane, in his presidential address to the American Political Science Association, observed that research diffusion was hindering the cumulative development of that field and proposed the organization of a comprehensive database. At about the same time, Carl Beck proposed that the United Nations organize a comprehensive database on peace research. ${ }^{30}$ Both proposals were dropped, failing to elicit sufficient interest.

In 1975 James McCartney organized a conference of sociology journal editors to establish some means of coordinating research dissemination. His concern was that high rejection rates of manuscripts meant that articles took three or four years to get published. His proposal to expedite the resubmission process by allowing editors to refer manuscripts directly to one another was not supported by the conference because of "many sociologists' fears against centralized planning and control of any form in the discipline." ${ }^{31}$

In 1976 David Mermin and Ken Wilson, physicists at Cornell University, responded to announcements of two new physics journals by writing a letter to Physics Today, urging for the sake of science libraries everywhere that people not support any such unnecessary new 
journals. As Mermin recalls, "From around the world we were attacked with a fury I couldn't have imagined. Many held us to be the running dogs of ... a blatant conspiracy to stifle [the marketplace of ideas]." ${ }^{32}$

By the latter half of the 1970s, scholars' concerns about the scholarly communication system had run its coursejust as interest began to gain momentum in the library field. The appearance of The National Enquiry at the end of the decade marked this disjuncture: the report was reviewed only in library and information science journals, with all reviewers remarking on its distinctive integrated-system approach. ${ }^{33}$

\section{University Presses}

In the 1970s the relationship between university presses and academic libraries was tightly coupled. Since then, it has loosened considerably as the presses, once utterly dependent upon library sales, have gained a more independent market position by deemphasizing their scholarly mandate. Such decoupling does not augur well for the scenario envisioned by librarians in which the presses would assume a much greater role in scholarly publishing.

Before 1970 the university presses typically published 2,000 copies of a scholarly monograph, even one intended for a specific audience. Since then, the average publication run for works in that category has been only about 500 copies. Gradually, the presses began publishing in other categories, such as mid-list books (serious nonfiction for the general public with projected sales of 2,000 to 10,000 copies), textbooks and reference works (with potential sales of 10,000 to 25,000 copies), and fiction. As a result, while the past twenty years have seen an almost unbroken decline in sales of scholarly monographs, university presses as a group have become bigger, healthier, and more diverse in their operations. ${ }^{34}$

University press directors apparently do not comprehend the librarian scenario of their taking charge of scholarly publishing. In all the literature, only one article written by a press director even refers to the idea. ${ }^{35}$ Press directors, who have been under university pressure for years to become completely self-sustaining, regard journal publishing-especially in science and technology fields-as too speculative (given the entrenched market positions of certain companies), too expensive (in terms of upfront capital investments), and not scholarly enough (since most of the presses do not play the same role in adding value to journals that they do with monographs).

\section{TIGHTLY COUPLED PATTERNS}

Analysis of interdependency in the scholarly communication system can be turned around and made more representative, by considering patterns of influence or interaction that are tightly coupled. Such patterns, involving direct means-end relationships in the system, are few in number but historically durable. They involve price discrimination, informal information exchange mechanisms, and academic rewards.

\section{Price Discrimination}

A number of studies on discriminatory pricing practices have come to the same conclusions, that the best journals discriminate the most against libraries (in the form of institutional prices) and that a few European firms discriminate the most against U.S. institutions. ${ }^{36}$

In view of the close relationship between price and quality, it is not surprising that library journal cancellations are only loosely coupled to journal prices. As Jean Haley and James Talaga found in an extensive survey, 80 percent of academic libraries tend to cancel less-expensive journals, whereas only one in six tend to cancel expensive ones. ${ }^{37}$

\section{Informal Information Exchange Mechanisms}

Earlier, mention was made of swift adjustments by learned societies to cut publication costs during the economic recession of the early 1970 s. At least a decade earlier, scholars had begun to make individual adjustments to a differ- 
ent problem-the flood of information. To cope with publication lags, they developed a variety of informal exchange mechanisms to expedite the transfer of information.

Most of what we know in any detail about this phenomenon was discovered in the Project of Scientific Exchange by the American Psychological Association (APA). In 1963, for example, half of the authors in core psychology journals distributed preprints, whereas by 1976 three of four authors distributed preprints and nearly all authors distributed reprints. As the APA observed, the "burden of dissemination of scientific information has, to some extent, been taken on by the authors themselves." ${ }^{38}$

\section{The publish-or-perish standard that} supposedly governs American higher education actually applies to only a small number of institutions.

Formal publication channels-being a year or two behind the scholars-became increasingly archival in character. In a study of 200 research projects in psychology during the late 1960 s, ideas for only one of seven projects originated from published sources, the inspiration instead coming from informal networks. ${ }^{39}$ More recent studies in other fields corroborate the primacy of informal exchange networks over formal publication channels in stimulating intellectual innovation. ${ }^{40}$

\section{Academic Rewards}

The strategy commonly advocated in the library field is simple in concept: administrators should make a concerted move toward quality-based measures of faculty research performance in order to displace the publish-or-perish syndrome of insignificant articles. This strategy is usually postulated in a paragraph or two without any consideration of its feasibility, or whether the sort of simplification it offers is justified.

Several considerations cast doubt on any such strategy. In the first place, the publish-or-perish standard that sup- posedly governs American higher education actually applies to only a small number of institutions. Most academics publish little or nothing in their careers. ${ }^{41}$ Publication proliferation is not an individual phenomenon but rather one of sheer mass. Consider the trend in U.S. doctoral programs: in 1960, 9,829 Ph.D. degrees were conferred; in 1970, 29,866; in $1986,34,829$; in $1990,38,283 .^{42}$

Ironically, as the numbers of scholars have multiplied, fewer people have the expertise to evaluate any particular piece of research because fields of knowledge have become increasingly specialized. Faculty committees have little choice but to rely on publication counts in administering the rewards system. Among its advantages-or virtues of its defects-are that such counts can be standardized (and weighted according to the reputation of the publisher); that they can be done in a reasonable amount of time, year after year; and, most important, that they remove personnel matters from campus politics, paradigm conflicts, and subjective issues of intellectual quality. ${ }^{43}$

Editorial boards have the relevant expertise, but no serious observer would claim that the manuscript review process is tightly coupled to objective criteria. Instead, even in the best of circumstances, such criteria tend to get displaced by certain random factors. Such factors include the availability of space for the acceptance of new papers and what is known as the luck-of-the-reviewer draw. In the social sciences and humanities, random factors account, by some estimates, for 50 percent of acceptor-reject decisions. In science and technology fields-having more "physical reality" to gauge research design, as well as more journal space-the role of chance is reduced to about 25 percent. ${ }^{44}$

As opposed to such loose coupling between manuscript review and intellectual quality, as well as between publish and perish, the academic rewards system is tightly coupled to numbers of publications. In terms of merit pay increases, economists have figured lifetime returns per article produced. ${ }^{45}$ In terms of pro- 
fessional recognition, sociologists have made the principles of accumulative advantage and the competence multiplier major themes in the literature. ${ }^{46}$

Thus, the strategy now espoused in the library field-to simultaneously increase research quality and decrease publication proliferation by changing the rewards system-would surely break down in any test. ${ }^{47}$ Finally, the academic rewards system is none of the business of librarians. As one administrator gently warned at an ARL meeting, "nothing is more likely to be misunderstood and to anger academics than even thoughtful comments on this subject." ${ }^{18}$

\section{ELECTRONIC PROSPECTS}

Development of the Internet as a global telecommunications network has largely reinforced the loosely coupled structure of the scholarly communication system. Management of the Internet resembles an "organized anarchy" with its philosophically pluralistic notions of decentralized initiative, local autonomy, and intellectual diversity. ${ }^{49}$ While use of the Internet-navigating its 11,000 semiautonomous networks, finding and downloading subjectspecific files-no longer requires much technical sophistication, widespread adoption of its command-driven protocols (file transfer and telnet, as opposed to mail) across the scholarly communication system remains problematic. Indeed, the literature paints a fairly bleak scenario in which the scholarly system becomes more or less balkanized along the lines of differing Internet competencies:

Gaps in network attitudes and skills exist along several dimensions: between older and younger researchers, between researchers and network administrators, between people in different sectors, between researchers from different disciplines, and between researchers working on different kinds or different stages of problems. ${ }^{50}$

In that broad respect, the Internet will likely contribute to internal divisions within the disciplines for some years.
The basic issue in the library field involves prospects for the development of a university-based electronic publishing apparatus, principally to resolve the serials crisis. Contrary to popular belief, such a development would likely exacerbate the current situation by (a) impairing intellectual innovation, (b) accelerating publication proliferation, and (c) intensifying price inflation.

First, consider certain basic decision rules in the editorial process for evaluating intellectual innovation. Science journals have acceptance rates in the $60-80$ percent range because they seek to minimize the chance that worthy papers will be rejected (a so-called Type I error), whereas social science journals have acceptance rates at the other end of the spectrum-in the 5-25 percent rangebecause they would rather risk rejecting a worthy paper than accepting an unworthy one. The latter situation (of avoiding a Type II error) is a condition of fields that are beset with differences over what problems are really important, what techniques are most useful, how much evidence is sufficient, and whether a solution to a given problem exists. ${ }^{51}$

If one rationale for a university-based publishing apparatus is to stem publication output by emphasizing quality control, turning around the decision rule for science journals from the established aim of avoiding Type I errors (rejection of a worthy paper) to a different aim of avoiding Type II errors (acceptance of a possibly unworthy paper) may disrupt intellectual risk taking and innovation.

Much the same can be said about a general publishing apparatus based on learned societies. They tend to be intellectually conservative and slow to develop a consensus on emerging research trends. Commercial publishers, in contrast, are concerned primarily with business risk and cannot afford to worry much about intellectual risk or conservatism. ${ }^{52}$

Now consider the potential for acceleration of publication proliferation in an electronic system. As noted, since the 1960 s journal space has become increasingly valuable, with upward to half of editorial decisions in the social sciences 
and humanities depending on the availability of space for the acceptance of new papers. (In science and technology, fewer editorial decisions depend on space constraints, since journals in those fields impose page charges, deal with much shorter manuscripts, and have a stronger consensus on how to apply criteria of intellectual quality.)

\section{Although criticism of the refereeing process as being too conservative or slow is commonplace, no other process is workable for full-text articles.}

Electronic journals, however, are not faced with space constraints. What happens when editors no longer must consider which papers merit the expense of publication? From a strictly economic standpoint, the refereeing process would be unnecessary:

No longer do we need to treat publication space as a precious resource to be doled out according to a schema of merit. Everything can be made available to everyone. We will no longer need a chosen few to do our choosing. ${ }^{53}$

Such a situation would serve no beneficial purpose. Although criticism of the refereeing process as being too conservative or slow is commonplace, no other process is workable for full-text articles (as opposed to the posting of abstracts of draft manuscripts on the Internet to elicit critiques).

Of historical note, in 1969 the APA started an Experimental Publication System as a way of dealing with growing publication backlogs. The idea was to publish an abstract of any paper submitted to it within sixty-five days of receipt (with papers available by mail). That experiment was discontinued after eight months because neither authors nor readers favored fast dissemination at the expense of the refereeing process. ${ }^{54}$

Thus, one can only hope that when scholarly journals go electronic, a kind of Gresham's law of publications-based on the fear that bad papers will drive out authors and readers-will keep traditional ground rules of the editorial process in place. By then, journal space scarcity based on economic cost will no longer enforce standards of intellectual quality.

Now, consider what would happen to the structure of knowledge under the simplistic scheme of each university becoming its own publisher. Universities rarely have enough faculty to provide in-depth coverage of a given research area; instead, faculty hiring is geared to broaden instructional coverage (i.e., a university hires only one or two professors of British history, or of comparative politics). If a university were to publish its own research, the literature in any given area would be dispersed over scores or hundreds of journals, rather than collected in a few specialized ones. Surely, there would be no economy or bibliographic control in that. Nor could the refereeing process be adequately handled on campus.

A necessarily more elaborate scheme would have universities publish specialized electronic journals in line with the international division of intellectual labor. What effect would that have on library subscription rates? Would university presses set rates more or less altruistically, at the cost of production-or would they treat journals as valuedadded commodities to be sold at market value? Richard Rowe suggests that universities would operate in a businesslike fashion:

With the economic pressures upon universities and with the shortening of the time frame between a scientific discovery and its commercial application for profit, . . . royalties from faculty products will be increasingly used as a source of revenue. I expect universities to look more and more to other intellectual products-the ideas, the publications, the writings of faculty -as potential sources of revenue to offset the escalating costs..$^{55}$

That view is also found in economic forecasts for American higher education. Universities, having increased tuition charges to maximum levels during the 
1980s, are generally adopting more opportunistic standards of entrepreneurial behavior. ${ }^{56}$

Over time, the scholarly communication system will become article-based, rather than journal-based. As Clifford Lynch observes, the ensuing financial environment may be far more volatile and complex than libraries are prepared to handle:

Libraries have assumed that prices per article would be relatively constant from one article in a given journal to another, and over relatively long time periods.... But it is easy to imagine publishers applying information technology to vary prices of articles over days or weeks, based on usage levels, topic interest, citation analysis, or media coverage. (A Nobel Prize, for example, might stimulate immediate doubling of prices for recent articles authored by the recipient.) One can imagine speculative markets in article futures much like a commodity market. Are libraries ready to ... adapt their budget and acquisitions policies to the realities of this new environment? ${ }^{57}$

Clearly, any major shift in the scholarly enterprise away from disinterested inquiry to ventures that are primarily profit-oriented would undermine the traditional rationale of the university press, as well as worsen the financial situation of academic libraries.

\section{SUGGESTIONS FOR FUTURE RESEARCH AND ANALYSIS}

Prospects for restructuring the scholarly communication system are nil. From a systems perspective, the overall configuration of loosely coupled patterns of influence or interaction vis-à-vis tightly coupled patterns are the reverse of what reformers would need. On the one hand, those patterns on which reformers would base a different system-academic library relations with university administrations, with university presses, with scholars, and with scholarly societiesare all loosely coupled, relatively weak, and hardly given to social engineering. On the other hand, those patterns which reformers seek to change-price inflation and discrimination, publication proliferation, and academic rewards-all involve tightly coupled patterns of cause and effect that are historically durable. Moreover, structural reform is not simply remote but also misguided because certain functional needs-for flexibility, local adaptation, and innovation-would likely be impaired. Nonetheless, some suggestions for future research and analysis in this area can be outlined in order to provide a few guidelines for determining what is practical and desirable.

\section{In Conceptual Matters, Look to Complexity and Controversy - Not to Simplicity and Interdependency}

In the library field, the usual approach to discussing structural reform of the scholarly communication system is to state seemingly plausible propositions, as if they could supply enough evaluation or incentive to spur action by other parties that would serve the interests of libraries. For example:

Universities should cease giving away the results of their research, only later to have academic libraries re-acquire the same information in the form of an expensive journal. Why not create a university-based publishing system? ? $^{58}$ Even when such a proposition is backed by some economic claim - "universities would save half a billion dollars" is the figure bandied about-this approach leads to nothing more than rhetoric. Indeed, that has been the situation over the past decade.

Since the scholarly communication system includes a multitude of segmented groups, each with quite different interests, any realistic approach to reform of the system would have to anticipate in some detail the difficulties in strategy, plans, and sequences of action that inevitably would occur. Policy makers in the groups will simply rule out of bounds structural reforms based on relatively narrow subsystem (academic library) interests as being uninteresting, too removed, or poorly understood, no matter how theoretically important. ${ }^{59}$

The great difficulty of basing analysis on what seems rational or plausible is 
finding and choosing a desirable position for one's own group (subsystem) that is at the same time acceptable to other groups and good for the system as a whole. Writers in the library field, for example, complain of publishers maximizing profits, of administrators simplifying the rewards system, of scholars turning out so-called LPUs (least publishable units of research), and so forth.

\section{An elementary theorem holds that loosely coupled systems provide greater room for self-determination than is true of more centralized systems, in which local adaptation and initiative are limited.}

Yet, writers in the library field expect university presses to assume not only a much greater subsidization of scholarly publishing but to do so in domains relatively foreign to their experience: science and technology journals. They would have university presses absorb heavy capital outlays, ignore the market value of publications, and price them at roughly the production cost. Such change would merely shift the financial burden from academic libraries to other budgets within the university. The "half billion dollars" in savings to universities is an amorphous claim.

Essentially the same problem is encountered when librarians urge administrators and scholars to make radical changes in the rewards system. What is noticeably missing is any suggestion of extra burdens for academic libraries. Indeed, the whole notion of a scholarly communication system in crisis has the effect of shifting the field of controversy from library resource-sharing to what other groups might do.

\section{In Policy Matters, Look to Disjointed Incrementalism and the Demonstration Effect-Not to Radical Reform}

The social engineering implicit in proposals to transform the publisher base or the rewards system is rare in democracies. It would require extraordinary intellectual and political comprehensiveness. Local needs and functional arrangements are liable to be "coordinated" out of sight by any grand plan. An elementary theorem holds that loosely coupled systems provide greater room for self-determination than is true of more centralized systems, in which local adaptation and initiative are limited. ${ }^{60}$

The essential point is that complex or controversial aspects of scholarly publishing - such as the function of journal space constraints, the role of Type I and Type II editorial decision rules, the difference between production cost and market value, and the prospect of universities practicing economic altruismshould not get lost or blunted through the arbitrariness of centralizing schemes. Such aspects must be fully considered before any scenario of structural reform will be taken seriously. Consider paper costs. Ann Okerson states that "by some accounts, dropping paper distribution cuts publishing costs approximately in half." ${ }^{61}$ Yet, libraries or computer centers will foot the bill for all the paper used to download thousands of articles from the Internet, many in multiple copies.

For those who remain steadfastly interested in pursuing structural reform, the first step would be to scale down grand scenarios to specific projects by deciding on a field and then make changes on an exploratory basis in order to determine what is actually possible and desirable. Such disjointed incrementalism would allow the opposition, the neutrals, and even the supporters to digest the process with a minimum of problems.

A logical field would be library and information science, where structural reform is already an institutionalized concept and the rewards system is not generally based on publication counts. Some questions directly pertinent to reform would crop up. According to $\mathrm{Li}$ brary Journal's latest survey, there are 118 journals in our field -is that too many? ${ }^{62}$ The average price is $\$ 60.81$ - is that too much? Price inflation has been 358 percent since 1977-is that, to an undue degree, the result of greed? Which uni- 
versity presses would volunteer to displace commercial presses and to practice price altruism?

If such an unlikely project proved moderately successful, we might have a case (in the form of demonstration effects) for encouraging projects in other fields. However, that prospect is weakened by the very nature of loosely coupled systems. Local autonomy allows such systems to respond to environmental change with more novel solutions than is true of tightly coupled systems. Yet, the very looseness of structure that allows subsystem innovations to flourish may retard their diffusion across the system. Thus, loosely coupled systems tend to have conspicuous cultural lags, as well as strong functional restraints on structural reforms. It is always easier to effect change within a subsystem than introduce change across subsystems. ${ }^{63}$ In the scholarly communication system, the strikingly different requirements of journal-based fields and book-based fields foreclose any general strategy of structural reform. ${ }^{64}$

All things considered, scenarios of grand structural reform will probably become a passing phase in the literature. The "logic of confidence" associated with loosely coupled systems-whereby parties expect each other to handle factors within their respective spheres of control-will compel us to return to themes of coordinated collection development once dominant in the 1970s. Whether that is a viable strategy remains to be seen. But greater attention to resource sharing is clearly preferable to another decade of rhetoric about overhauling the scholarly communication system as a whole in order to resolve certain problems confronting academic libraries.

\section{Postscript}

Some of our idealism in face of the serials crisis has rested on the assumption of system interdependency-that although different constituencies may adopt conflicting approaches to particular problems, the "binding forces, the common interests, are ultimately stronger." To shift our assumption-ground to one based on a loosely coupled system does not imply an end to optimism. But it should remind us of the simple truth that America has no national consensus about what constitutes the good scholarly communication system. Recognition of complexity and controversy should be an intellectual stimulus in the coming debate, not a provocation for either wishful or pessimistic scenarios. The challenge is to summon our own considerable collective ingenuity, focusing on systemwide perspectives and field-specific exemplars, to demonstrate what is possible and desirable.

\section{REFERENCES AND NOTES}

1. Stevan Harnad, "Post-Gutenberg Galaxy: The Fourth Revolution in the Means of Production of Knowledge," The Public-Access Computer Systems Review 2, no. 1 (1991): 39-53, e-mail retrieval: mail Listserv@uhupvm1.uh.edu. Get HARNAD PRV2N1 $\mathrm{f}=$ mail. For an overview of electronic prospects, see Eldred Smith, "Resolving the Acquisitions Dilemma: Into the Electronic Information Environment," College \& Research Libraries 52 (May 1991): 231-40.

2. Richard M. Dougherty, "Turning the Serials Crisis to Our Advantage: An Opportunity for Leadership," Library Administration \& Management 3 (Spring 1989): 59-64; Scott Bennett and Nina Matheson, "Scholarly Articles: Valuable Commodities for Universities," Chronicle of Higher Education 38 (May 27, 1992): B1-3. For an overview of the literature on a university-based publishing apparatus, see Ann Okerson, "With Feathers: Effects of Copyright and Ownership on Scholarly Publishing," College \& Research Libraries 52 (Sept. 1991): 425-38.

3. Herbert S. White, "Scholarly Publication, Academic Libraries, and the Assumption that These Processes Are Really under Management Control," College \& Research Libraries 54 (July 1993): 293-301. For an overview of the interplay between academic rewards and scholarly publishing, see Dennis P. Carrigan, "Publish or Perish: The Troubled State of Scholarly Communication," Scholarly Publishing 22 (Apr. 1991): 131-42. 
4. James C. Thompson, "Journal Costs: Perceptions and Reality in the Dialogue," College \& Research Libraries 49 (Nov. 1989): 482.

5. Ronald F. Dow, Karen Hunter, and G. Gregory Lozier, "Commentaries on Serials Publishing," College \& Research Libraries 52 (Nov. 1991): 524.

6. National Enquiry into Scholarly Communication, Scholarly Communication: The Report of the National Enquiry (Baltimore, Md.: Johns Hopkins Univ. Pr., 1979), xi.

7. Ibid., 6 .

8. Charles B. Osburn, "Collection Development and Management," in Academic Libraries: Research Perspectives, ed. Mary Jo Lynch and Arthur Young (Chicago: ALA), 26-27.

9. Michael D. Cohen, James G. March, and Johan P. Olsen, "A Garbage Can Model of Organizational Choice," Administrative Science Quarterly 17 (Mar. 1972): 1-25; Kim Cameron, "Critical Questions in Assessing Organizational Effectiveness," Organizational Dynamics 9 (Autumn 1980): 66-80.

10. For example, the American Political Science Association cut most of the book review section in The American Political Science Review, the Modern Language Association dropped many articles planned for the PMLA, and the American Economic Association omitted the author index in the Journal of Economic Literature. See Fritz Machlup, "Publishing Scholarly Books and Journals: Is It Economically Viable?" Journal of Political Economy 85 (Feb. 1977): 217-25; and "Perspectives on Publishing" (issue theme), Annals of the American Academy of Political and Social Science 421 (Sept. 1975), ed. Philip G. Altbach and Sheila McVey.

11. Bernard M. Goldman et al., "Critiquing the National Enquiry," Book Forum 5 (1979): 63-78.

12. Ibid., 67.

13. Karl E. Weick, "Educational Organizations as Loosely Coupled Systems," Administrative Science Quarterly 21 (Mar. 1976): 1-19; Karl E. Weick, "Management of Organizational Change among Loosely Coupled Elements," in Change in Organizations, ed. Paul S. Goodman and Associates (San Francisco: Jossey-Bass, 1982), 375-408; Herbert A. Simon, "How Complex Are Complex Systems?," PSA: Proceedings of the Biennial Meeting of the Philosophy of Science Association 2 (1976):507-22.

14. Osburn, "Collection Development," 29.

15. Charles A. Schwartz, "Book Selection, Collection Development, and Bounded Rationality," College \& Research Libraries 50 (May 1989): 328-43.

16. For various conceptualizations, see Charles B. Osburn, "The Structuring of the Scholarly Communication System," College \& Research Libraries 50 (May 1989): 277-86; P. J. Hills, "The Scholarly Communication Process," Annual Review of Information Science and Technology 18 (1983): 99-125; Warren J. Haas, "Computing in Documentation and Scholarly Research," Science 215 (Feb. 12, 1982), 857-61; Association of Research Libraries, "The Changing System of Scholarly Communication," Information Reports and Bibliographies 15: (1986): 2-6; Thomas. W. Shaughnessy et al., "Scholarly Communication: The Need for an Agenda for Action-A Symposium," Journal of Academic Librarianship 15 (May 1989):68-78.

17. J. Douglas Orton and Karl E. Weick, "Loosely Coupled Systems: A Reconceptualization," Academy of Management Review 15 (Apr. 1990): 204.

18. Robert F. Munn, "The Bottomless Pit, or the Academic Library as Viewed from the Administration Building," College \& Research Libraries 29 (Jan. 1968): 51-54; Patricia Battin, "The Library: Center of the Restructured University," College \& Research Libraries 45 (May 1984): 170-76.

19. John W. Meyer and Brian Rowan, "The Structure of Educational Organizations," in Organizational Environments: Ritual and Rationality, ed. John W. Meyer and W. Richard Scott (Newbury Park, Calif.: Sage, 1983), 90.

20. Robert M. O'Neil, "Academic Libraries and the Future: A President's View," College \& Research Libraries 45 (May 1984): 184-88; Lloyd W. Chapin, "Librarians and Campus Administrators: Working Together to Support the Library," Library Issues: Briefings for Faculty and Administrators 10 (Mar. 1990).

21. Herbert S. White, "The OK Corral University Library Revisited," Library Journal 114 (Nov. 15, 1989): 63. 
22. Dennis P. Carrigan, "The Political Economy of the Academic Library," College \& Research Libraries 49 (July 1988): 325-31; Larry Hardesty, "The Bottomless Pit Revisited," College \& Research Libraries 52 (May 1991): 219-29. Recent surveys reveal great difficulties when administrators and library directors attempt to move from rhetoric about abstract concepts to the formulation of explicit goals for the future of information resources and services on campus. See Richard M. Dougherty and Carol Hughes, Preferred Futures: A Summary of Six Workshops with University Provosts and Library Directors (Mountain View, Calif.: Research Libraries Group, 1991); and Carol A. Hughes, "A Comparison of Perceptions of Campus Priorities: The 'Logical' Library in an Organized Anarchy," Journal of Academic Librarianship 18 (Mar. 1992): 140-45.

23. Paul H. Mosher and Marcia Pankake, "A Guide to Coordinated and Cooperative Collection Development," Library Resources and Technical Services 27 (Oct./Dec. 1983): 417-31.

24. Robert B. Downs, "American Library Cooperation in Review," College \& Research Libraries 6 (Sept. 1945, part II): 411.

25. Charles A. Schwartz, "Social Science Perspectives on Cooperative Collection Development," in Impact of Technology on Resource Sharing: Experimentation and Maturity, ed. Thomas C. Wilson (Binghamton, N.Y.: Haworth, 1992), 47-60.

26. Joe A. Hewitt and John S. Shipman, "Cooperative Collection Development among Research Libraries in the Age of Networking: Report of a Survey of ARL Libraries," Advances in Library Automation and Networking 1 (1987): 189-232; Joseph J. Branin, "Cooperative Collection Development," in Collection Development: A New Treatise, ed. Charles B. Osburn and Ross Atkinson, (Greenwich, Conn.: JAI Pr., 1991), 81-110; Richard Hacken, "The RLG Conoco Study and Its Aftermath: Is Resource Sharing in Limbo?," Journal of Academic Librarianship 18 (Mar. 1992): 17-23.

27. Blaise Cronin, "Invisible Colleges and Information Transfer," Journal of Documentation 38 (Sept. 1982): 212-36; L. S. Bourne, "Different Solitudes and the Restructuring of Academic Publishing: On Barriers to Communication in Research," Environment and Planning: A 20 (Nov. 1988): 1423-25.

28. William E. Vandament, "Primer for Academic Administrators," Change 14 (Sept. 1982): 43.

29. For example, the November 1990 issue of Psychological Science has as its theme "intellectual perestroika" through electronic publishing; in eleven articles, libraries are mentioned only twice- once to suggest their demise (p. 348).

30. Robert E. Lane, "To Nurture a Discipline," American Political Science Review 181 (Mar. 1972): 66; Carl Beck, "Peace Research and Information Systems," in UNESCO Yearbook on Peace and Conflict Studies (Westport, Conn.: Greenwood, 1980), 14-24.

31. James L. McCartney, "Confronting the Journal Publication Crisis: A Proposal for a Council of Social Science Editors," American Sociologist 11 (Aug. 1976):144-52.

32. N. David Mermin, Boojums All the Way Through: Communicating Science in a Prosaic Age (New York: Cambridge Univ. Pr., 1991), 58.

33. W. L. Williamson, review of The National Inquiry, in Library Quarterly 50 (July 1980): 370-71; David Kaser, review of The National Enquiry, in Library Journal 104 (Oct. 15, 1979), 2179; K. G. Peterson, review of The National Enquiry, in College \& Research Libraries 40 (Nov. 1979):555-57.

34. Ellen K. Coughlin, "Years of Adversity, Decade of Growth Change Face of University Publishing," Chronicle of Higher Education 36 (June 27, 1990), A1, A8-9; Will Nixon, "University Presses: Highs \& Lows," Publishers Weekly 236 (Sept. 22, 1989), 18-24; Colin Day, "The University Press: An Organic Part of the Institution," Scholarly Publishing 23 (Oct. 1991): 27-44.

35. Stanford G. Thatcher, "Towards the Year 2000," Scholarly Publishing 24 (Oct. 1992): 25-37.

36. Kenneth E. Marks et al., "Longitudinal Study of Scientific Journal Prices in a Research Library," College \& Research Libraries 52 (Mar. 1991): 125-38; Patrick Joyce and Thomas E. Merz, "Price Discrimination in Academic Journals," Library Quarterly 55 (July 1985): 273-83.

37. Jean Walstrom Haley and James Talaga, "Academic Library Responses to Journal Price Discrimination," College \& Research Libraries 53 (Jan. 1992):61-70. 
38. William D. Garvey and Beverly C. Griffith, "Scientific Communication: Its Role in the Conduct of Research and Creation of Knowledge," American Psychologist 26 (Apr. 1971): 357; William D. Garvey, Stephen D. Gottfredson, and James G. Simmons, "A Comparison of Two Major Scientific Information Exchange Processes in Psychology," American Psychologist 39 (Jan. 1984): 20.

39. Garvey and Griffith, "Scientific Communication," 354.

40. Herbert C. Morton and Anne Jamieson Price, The ACLS Survey of Scholars: Views on Publications, Computers, and Libraries (Washington, D.C.: American Council of Learned Societies, 1989); Walter R. Nord, "Looking at Ourselves as We Look at Others: An Exploration of the Publication System for Organization Research," in Publishing in the Organizational Sciences, ed. L. L. Cummings and Peter J. Frost (Homewood, Ill.: Irwin, 1985), 76-88.

41. For an overview, see Charles A. Schwartz, "Research Productivity and Publication Output: An Interdisciplinary Analysis," College \& Research Libraries 52 (Sept. 1991): 414-24.

42. Digest of Educational Statistics (Washington, D.C.: Govt. Print. Off., 1990), 166; Chronicle of Higher Education Almanac 39 (Aug. 26, 1992): A15.

43. Robert E. McCormick and Roger E. Meiners, "University Governance: A Property Rights Perspective," Journal of Law and Economics 31 (Oct. 1988): 423-42.

44. Marley W. Watkins, "Chance and Interrater Agreement on Manuscripts," American Psychologist 34 (Sept. 1979): 796-97; Stephen Cole, Jonathan R. Cole, and Gary A. Simon, "Chance and Consensus in Peer Review," Science 214 (Nov. 20, 1981), 881-85; Grover J. Whitehurst, "Interrater Agreement for Journal Manuscript Review," American Psychologist 39 (Jan. 1984): 22-28.

45. Howard P. Tuckman and Jack Leahey, "What Is an Article Worth?" Journal of Political Economy 83 (1975): 951-67; Katherine Lewellan Kasten, "Tenure and Merit Pay as Rewards for Research, Teaching, and Service at a Research University," Journal of Higher Education 55 (July/Aug. 1984): 500-14.

46. Robert K. Merton, Social Research and the Practicing Professions (Cambridge, Mass.: Abt Books, 1982), 8.

47. For a satire on faculty members' behavior when the system for measuring scholarly merit is radically changed, see George J. Stigler, The Intellectual and the Marketplace (Cambridge, Mass.: Harvard Univ. Pr., 1984), 3-9.

48. Stanley Katz, "Meeting the Needs of Tomorrow's Scholars," Minutes of the 114th Meeting (Washington, D.C.: Assoc. of Research Libraries, 1990), 10.

49. On the Internet as a loosely coupled system, see Murli Nagasundaram and Gerald R. Wagner, "Ambiguity in Human Communication and the Design of Computer-Mediated-Communication Systems," Information Systems: Proceedings of the Hawaii International Conference on System Science 4 (1992): 90-100; Edwin B. Brownrigg, "The Internet as an External Economy: The Emergence of the Invisible Hand," Library Administration \& Management 5 (Spring 1991): 95-97.

50. Charles R. McClure et al., The National Research and Education Network (NREN): Research and Policy Perspectives (Norwood, N.J.: Ablex, 1991), chap. 6; Vartan Gregorian, "Technology, Scholarship, and the Humanities: The Implications of Electronic Information," (Paper presented at a conference on Technology, Scholarship, and the Humanities: The Implications of Electronic Information, Getty Art History Information Program, Sept. 30/Oct. 2, 1992.) Anonymous ftp: FTP.CNI.ORG; cd/CNI/documents/tech.schol.human/papers . Binary . Get GREGORIAN.WP ; M. Lynn Markus, 'Toward a 'Critical Mass' Theory of Interactive Media: Universal Access, Interdependence, and Diffusion," Communication Research 14 (Oct. 1987): 492; Starr Roxanne Hiltz, Online Communities (Norwood, N.J.: Ablex, 1984), 9.

51. Jeffrey Pfeffer, Anthony Leong, and Katherine Strehl, "Paradigm Development and Particularism: Journal Publication in Three Scientific Disciplines," Social Forces 55 (June 1977): 938-51; Janice Beyers, "Editorial Policies and Practices among Leading Journals in Four Scientific Fields," Sociological Quarterly 19 (Winter 1978): 68-88; Von Bakanic, Clark McPhail, and Rita J. Simon, "The Manuscript Review and Decision-Making Process," American Sociological Review 52 (Oct. 1987): 631-42; Lowell L. Hargens, 
"Scholarly Consensus and Journal Rejection Rates," American Sociological Review 53 (Feb. 1988):139-51.

52. Irving Louis Horowitz, Communicating Ideas: The Crisis of Publishing in a Post-Industrial Society (New York: Oxford Univ. Pr., 1986), 34.

53. Scott Shamp, "A Functional Analysis of the Review Process and Electronic Journals," Feedback 30 (Summer 1989): 6; Sharon Rogers and Charlene Hurt, "How Scholarly Communications Should Work in the 21st Century," Chronicle of Higher Education 35 (Oct. 18, 1989): A56.

54. R. G. Kinkade and John A. Whittenburg, The Results of Operating an Experimental Publication System: An Interim Report (Washington, D.C.: American Psychological Assoc., 1970).

55. Richard R. Rowe, "The Economics of Scholarly Communication," Library Acquisitions: Practice \& Theory 13 (1989): 426.

56. Roger L. Geiger, "Research Universities in a New Era: From the 1980s to the 1990s," in Higher Learning in America: 1980-2000, ed. Arthur Levine (Baltimore: Johns Hopkins Univ. Pr., 1993), 67-85.

57. Clifford Lynch, "The Transformation of Scholarly Communication and the Role of the Library in the Age of Networked Information," Serials Librarian 23 (no. 3-4): 11.

58. Abridged from Dougherty, "Turning the Serials Crisis."

59. David Braybrooke and Charles E. Lindblom, A Strategy of Decision: Policy Evaluation as a Social Process (New York: Free Pr., 1963), 90.

60. Weick, "Educational Organizations," 7-8; Donald R. Swanson, "Libraries and the Growth of Knowledge," Library Quarterly 49 (Jan. 1979): 3-25 ; Harold Billings, "Governing Library Networks: The Quick and the Dead for the 1990s," Library Journal 114 (Nov. 1, 1989), 49-54.

61. Ann Okerson, "Back to Academia? The Case for American Universities to Publish Their Own Research," Logos 2 (1991): 110.

62. Adrian W. Alexander and Kathryn Hammell Carpenter, "Periodical Price Index for 1993," Library Journal 118 (May 1993): 438. For an idealistic account of how structural reform would affect personal behavior, see "Ten Things You Can Do to Help in the Scholarly Communication Crisis," College \& Research Library News 53 (Oct. 1992): 582. On the irrationality of such behavior from a systems perspective, see Gary D. Bryd, "An Economic 'Commons' Tragedy for Research Libraries: Scholarly Journal Publishing and Pricing Trends," College \& Research Libraries 51 (May 1990): 184-95.

63. Weick, "Educational Organizations," 7; Simon, "How Complex Are Complex Systems?" 513.

64. Compare, for example, the "Report of the APS Task Force on Electronic Information Systems," Bulletin of the American Physical Society, Series II, 36 (Apr. 1991): 1119-51 to the position of the Modern Language Association in Phyllis Franklin, "Scholars, Librarians, and the Future of Primary Records," College \& Research Libraries 54 (Sept. 1993): 397-406. 


\section{We've kept track of Bill Clinton's career...}

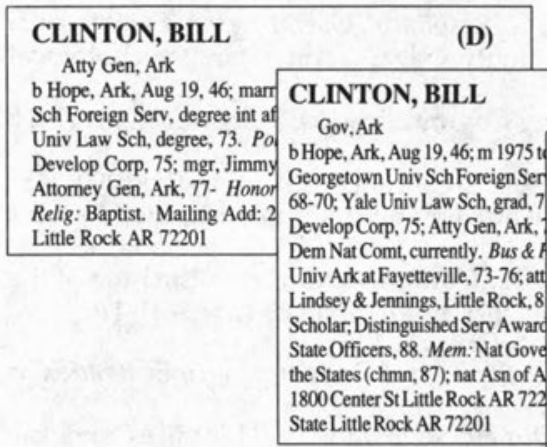

\section{CLINTON, BILL}

(D)

President of the United States

b Hope, Ark, Aug 19, 46; m 1975 to Hillary Rodham; c Chelsea. Educ:

Georgetown Univ Sch Foreign Serv, grad, 68; Oxford Univ, 68-70; Yale Univ Law Sch, grad, 73. Polit \& Govt Pos: Chmn, Housing Develop Corp, 75; Atty Gen, Ark, 77-79; Gov, Ark, 79-81, 83-93; President of the US, 1993-; mem, Dem Nat Comt, currently. Bus \& Prof Pos: Prof of Law, Sch of Law, Univ Ark at Fayetteville, 73-76; atty, pvt practice, 73-76, mem, Wright, Lindsey \& Jennings, Little Rock, 81-82. Honors \& Awards: Rhodes Scholar, Distinguished Serv Award, Coun Chief State Officers, 88. Mem: Nat Govemor's Asa (chmn, 87); Educ Comn of the States (chmn, 87); Nat Asn of Atty Gens. Relig: Baptist. Legal Res: 1800 Center St Little Rock AR 72206 Mailing Add: Office of the President, 1600 Pennsylvania Ave NW, Washington DC 20500.

\section{and 26,000 others.}

\section{Who's Who in American Politics 1993-1994}

The only source auailable that coters the full range of U.S. politics ... indispensable for any respectable reference collection."

\section{- AMERICAN REFERENCE BOOKS ANNUAL}

\section{Featuring over 2,000 new entries!}

Bill Clinton wasn't the only one to get a new job as a result of the last national election ... it ushered in a host of new people in new positions all across the country.

From the President to local politicians, Who's Who in American Politics 1993-94 is the only source for current biograpbical information on over 26,000 elected and appointed officials, party functionaries, former office bolders, and more.
The personal bistories of people making beadlines today Featuring over 2,000 new office-holders, Who's Who in American Politics 1993-94 gives you accurate biographical listings - information you can count on because it's provided by the entrants themselves ... $100 \%$ of the existing entries have been updated or verified since the previous edition.

\section{PLACE A STANDING ORDER AND SAVE!}

Place a new standing order for Who's Who in American Politics and you'll save $5 \%$ off the list price. Plus, you'll get $5 \%$ off all future editions.

$1993 \cdot 0-8352-3285-9 \cdot 2-v o l$. set $\bullet 2,113 p p$. $\bullet \$ 225.00$ Available on Standing Order

\section{Also of Interest}

Who's Who in European Politics, 2nd Edition - accurate information on over 8,000 European politicians.

A Bowker.Saur tille.

Febriary $1993 \cdot 1-85739-021-0 \cdot 1,016$ pp. $\bullet \$ 300.00$

Available on Standing Order.

\section{Call toll-free}

\section{1-800-521-8110}

dial 1 for Customer Service, and ask for Department FXQ3. Or fax your order to: (908) 665-6688.
Marquis Who's Who of American Women 1993-1994, 18th Edition

- insightful biographical facts on more than 27,500 achievers.

A Marquis Who's Who title.

Febriary 1993 • 0-8379-0418-8 • 1,083 pp. • \$225.00

Available on Standing Order.

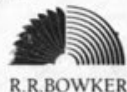

A Reed Reference Publishing Company 121 Chanlon Road, New Providence, NJ 07974 